AperTO - Archivio Istituzionale Open Access dell'Università di Torino

\title{
Some Remarks on Analogy, Reanalysis and Grammaticalization
}

\section{This is the author's manuscript}

Original Citation:

Availability:

This version is available http://hdl.handle.net/2318/128049

since

Publisher:

John Benjamins

Terms of use:

Open Access

Anyone can freely access the full text of works made available as "Open Access". Works made available under a Creative Commons license can be used according to the terms and conditions of said license. Use of all other works requires consent of the right holder (author or publisher) if not exempted from copyright protection by the applicable law. 
TYPOLOGICAL STUDIES IN LANGUAGE (TSL)

A companion series to the journal "STUDIES IN LANGUAGE"

\section{Honorary Editor: Joseph H. Greenberg}

General Editor: Michael Noonan

Assistant Editors: Spike Gildea, Suzanne Kemmer

\section{Editorial Board:}

Wallace Chafe (Santa Barbara) Bernard Comrie (Los Angeles)

R.M.W. Dixon (Canberra)

Matthew Dryer (Buffalo)

John Haiman (St Paul)

Kenneth Hale (Cambridge, Mass.)

Bernd Heine (Köln)

Paul Hopper (Pittsburgh)

Andrej Kibrik (Moscow)
Ronald Langacker (San Diego)

Charles Li (Santa Barbara)

Andrew Pawley (Canberra)

Doris Payne (Oregon)

Frans Plank (Konstanz)

Jerrold Sadock (Chicago)

Dan Slobin (Berkeley)

Sandra Thompson (Santa Barbara)

\title{
THE LIMITS OF \\ GRAMMATICALIZATION
}

Edited by

\author{
ANNA GIACALONE RAMAT \\ University of Pavia
}

PAUL J. HOPPER

University of Pittsburgh

Volumes in this series will be functionally and typologically oriented, covering specific Vopict variety of languages and language topics in language by collecting the typologies. The orientation of the volumes will be substan as aim of investigating universals of human language via as broadly defined a discourse data possible, leaning toward cross-linguistic, diachronic, developmental and live-discour $\mathrm{Li}$ (Word The series is, in spirit as well as in fact, a continuation of the tradition initictic Change) and Order and Word Order Change, Subject and Topic, Mech Order and Wor T. Givón (Discourse and Syntax) and P. Hopper (Tense-Aspect: Between Semantics and Pragmatics)

Volume 37

Anna Giacalone Ramat and Paul J. Hopper (eds)

The Limits of Grammaticalization

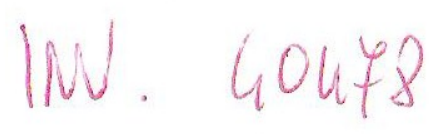

JOHN BENJAMINS PUBLISHING COMPANY AMSTERDAM/PHILADELPHIA 
Traugott, Elizabeth C. and Ekkehard König. 1991. "The semantics-pragmatics of grammaticalization revisited." In Elizabeth C. Traugott and Bernd Heine (eds.), 189-218.

Traugott, Elizabeth C. and Bernd Heine (eds.). 1991. Approaches to Grammaticalization Amsterdam and Philadelphia: John Benjamins.

\section{Some remarks on anallogy, reanalysis and grammaticalization*}

\author{
Livio Gaeta \\ Terza Università di Roma
}

\subsection{Introduction}

As is well known, grammaticalization is, according to Meillet (1912), the term for those linguistic changes that have as input lexemes (or lexical forms) which become more or less grammatical formatives. Following his seminal idea, two "clines" of grammaticalization have been singled out (cf. Hopper \& Traugott 1993: 7):

- the cline of grammaticality, concerning "syntactic" phenomena of grammaticalization, such as cliticization, affix-formation, etc.;

- the cline of lexicality, concerning more specifically the evolution of free lexical forms into word formation affixes (through a compounding stage).

Meillet and his followers, however, have used in my opinion the term grammaticalization both over-generously and injudiciously. As has been pointed out by others (cf. Hopper 1994), grammaticalization, in its broader meaning, has to do with the whole range of phenomena that give rise to grammatical formatives, not merely with those originating from lexical forms. This assumption that grammaticalization originates mostly from lexical forms is probably revealing of the working attitude of those scholars who have devel-

* This paper has been presented at the Workshop on "Diachronic perspectives in grammaticalization" during the XXVIII Annual Meeting of the Societas Linguistica Europaea held in Leiden in September, 1995. I thank Georgi Jetchev, the scholars attending the wuropaea held in Leiden editors for helpful comments and suggestions. Needless to attending the workshop as well as the are my own. 
oped Meillet's original idea by considering grammar and grammatical change as more related to syntax and discourse than to other components of the language. To reverse this custom, I will consider here the case of the "phonological" way to grammaticalization (also called grammaticalization "from below", cf. Greenberg 1991: 303), i.e. the case of originally phonological rules that get involved with more or less advanced processes of morphologization, to use the term closest to grammaticalization. ${ }^{1}$

\subsection{Grammaticalization and morphologization}

It is noteworthy, in this perspective, to take into consideration two different definitions of morphologization, revealing the different points of view of the respective authors. The first definition is borrowed from the recent handbook of Hopper \& Traugott (1993: 130), in which morphologization is the "compacting - the fusing of erstwhile independent elements with each other, most especially the development of clitics into inflections". In other words, "morphologization is that part of grammaticalization that primarily involves the second and third step of the cline [of lexicality]: lexical item > clitic > affix (p. 132)". That other uses of the term morphologization are not ignored by the authors is shown by the note they add (p. 224), in which they specify that "the form 'morphologization' is sometimes also used for the development of phonological alternations that occur as the result of phonological changes in specific morphological contexts, in other words, of morphophonemic alternations, as found in the English past tense form -ed ([t - d - ed])". Actually, the example they provide shows a partial misunderstanding of the kind of linguistic change that goes under the name of morphologization. The sound alternation involved in the English past tense form is correctly an instance of morphophonology, namely of a morphologically conditioned phonological alternation (cf., among others, Dressler 1985). As an instance of morpho(pho)nemic alternation, the quoted example appears however to be quite different from the morphologization of phonological rules. In fact, the crucial point is that it is not anchored in synchronic morphological alternation (cf. Klausenburger 1979). The purpose of the rule remains, in a sense, phonologically oriented (in the quoted example: sonority assimilation to the preceding phoneme), whereas in case of true morphologizations the purpose becomes of a morphological kind, i.e. to convey a specific semantic/gram- matical function. In this sense, a correct and strict definition of morphologization is that provided by Wurzel (1980: 444):

\begin{abstract}
"morphologizing, as we understand it, holds whenever a rule, which so far logical context $P$, changes in a way that it hold necessarily only this one) or its inversion in a the same operation (not categories C. A rule, whose original (mersion in a context of grammatical to adapt a set of phonetic sunction it was tic sequences to human speech organs, takes over basically new function of formally marking words. Thus the complete or partial marking grammatical categories in substituted by a semiotic motivation". phonetic motivation of the rule is
\end{abstract}

This long quotation will serve as a background for the presentation of data which follows. To briefly summarize the discussion, it seems useful to me not to restrict the term grammaticalization to the more specific uses mentioned above. Otherwise, we would be faced with quite a paradoxical (and misleading tere general term, i.e. grammaticalization, is assumed to designate a rather specific set of phenomena, whereas the more specific term morphologization turns out to be so wide as to cover, besides instances of grammaticalization, other kinds of changes that somehow "enrich" the grammar of a language.

\subsection{The path of grammaticality}

In the article quoted, Wurzel showed a range of phenomena that go under the name of morphologizations. They all involve the more general assimilative rule of Umlaut. In this respect, one can observe that morphologizations generally find their starting point in morphonologizations, i.e. in the introduction of grammatical features into the context of a phonological rule (see the above example of the English past tense form). However, one can speak of morphologization, when the last remainder of the sequential phonological environment is deleted from the context of the rule, that, in this way, "becomes free for categorial marking independently of phonological context conditions" (Wurzel 1980: 445).

Let us give a look now at the following example of morphologization Wurzel provides. In Old High German $(=\mathrm{OHG})$ there are the following noun paradigms respectively for masculine $i$-stems and $n$-stems: 
(1) N. Sg. gast 'guest' Pl. gast Sg. hano 'cock' Pl. hanun

$\begin{array}{lllll}\text { G. } & \text { gastes } & \text { gestio } & \text { henin } & \text { hanôno } \\ \text { D. } & \text { gaste } & \text { gestim } & \text { henin } & \text { hanôn } \\ \text { A. } & \text { gast } & \text { gesti } & \text { hanun } & \text { hanun } \\ \text { I. } & \text { gestiu } & - & - & -\end{array}$

The sound alternation a/e in the nominal root is caused by the Umlaut rule, which functions at this stage phonologically:

$$
\text { (Ur)a } \quad \mathrm{V} \rightarrow[+ \text { front }] / \mathrm{C}_{1}\left[\begin{array}{l}
- \text { consonant } \\
- \text { back } \\
+ \text { high }
\end{array}\right]
$$

After a rather unclear stage where umlauted forms begin to be ruled out morphologically, ${ }^{2}$ we find the following situation in Middle High German (=MHG):

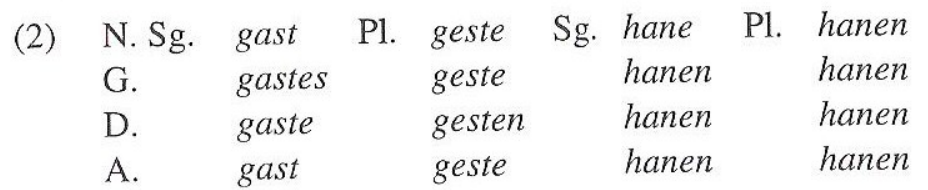

At this stage, the originally phonological rule of Umlaut has become morphologically conditioned: it occurs namely only in the plural of $i$-nouns, and it has been completely ruled out from $n$-nouns. According to Wurzel, we can represent now the Umlaut rule in the following way:

$$
(\mathrm{Ur}) \mathrm{b} \quad \mathrm{V} \rightarrow[+ \text { front }] /\left[\begin{array}{l}
+\mathrm{i} \text { - Inflect } \\
+ \text { Masculine } \\
+ \text { Plural }
\end{array}\right]
$$

Clearly, for the reanalysis of the (Ur)a to take place, it was necessary for some other changes to happen, and particularly the weakening of vowels in unstressed final syllables. This phonological change was the crucial factor that favoured the process of reanalysis: it creates what is a kind of affix, or at least a "discontinous morpheme" (cf. Salmons 1994: 215). This kind of grammati calization of an early phonological rule into an inflectional rule can be understood as belonging to the path of grammaticality, a kind of reverse path to that starting with lexical forms:

- phonological rule $>$ (morphophonological alternation) $>$ affix
Notice that this path presupposes an intermediate step, in which the alternation is morphonologically governed. This corresponds also to the observation of Wurzel (1980) that morphologizations (of phonological rules) begin as morphonologizations. Generally, the proper morphologization takes place as a consequence of the complete "decay of phonological alternations based on which the alternation had functioned so far" (cf. Wurzel 1980: 457).

\subsection{The cline of lexicality}

A cline of lexicality, symmetrical to the path of grammaticalization described above, can be assumed. Here, an originally phonological rule gets grammaticalized as a word formation device. The latter case points to the grammaticalization of early phonological rules as derivational affixes, which are able to create new lexical words. ${ }^{3}$

An example of a new derivational affix produced by grammaticalization to be found in literature is the so-called Cheshirization, where the original morpheme disappears leaving only a phonological alternation as its trace, like Lewis Carroll's Cheshire Cat, who disappeared leaving only its smile. For example, in Lahu, a Lolo-Burmese language of Northern Thailand, an original causative prefix, probably $*$-, underlies alternations between voiced and voiceless initials in such pairs as:

(3) a. [dう̀] 'drink' : [to] 'give to drink'

b. $[\mathrm{d} \varepsilon \bar{\varepsilon}]$ 'come to rest' : [tع] 'put down'4

A similar alternation also existed in Germanic, due to the presence of the causative suffix -jan, which served to make causative verbs from verbal roots (cf. Meillet 19304: 155):

(4) got. drigkan 'drink' : dragkjan 'give to drink'

The vocalism of the derived verbal root is $a(<\mathrm{PIE} * o)$, and the suffix is stress-bearing, which gives rise, in the course of further developments, to other sound alternations (see below beißen-beizen), that are however irrelevant for the present purposes.

In $\mathrm{OHG}$, the suffix -jan triggered the rule of Umlaut, giving rise to the following alternations, that still survive in New High German (= NHG, cf.
Paul 1920: 125): 
(5) trinken 'to drink' : tränken 'to water' beißen 'to bit' : beizen 'to annoy' walzen 'to laminate' : wälzen 'to roll'

What is relevant to our purposes is the observation of Wilmanns (19302: 62) that "erscheint der Umlaut als ein Mittel der Ableitung und dringt so selbst in solche Verba ein, die ursprünglich der 2. oder 3. Conjugation folgten". This verb class fluctuation is quite widespread in $\mathrm{OHG}$ and it goes further in MHG ${ }^{5}$ tied in with a semantic differentiation of the verbal "Aktionsart" (cf. Krämer 1971: 66):

(6) sprangôn 'spring' : sprengen 'make to spring' hwarbôn 'transform' : hwerben 'turn' zartôn 'flatter' : zerten 'stroke' krachôn 'creak' : krecken 'shake' ga-langôn 'reach' : lengen 'lengthen' lazzôn 'slow down' : lezzen 'hold back'

By "Aktionsart" proper, Krämer means a semantic differentiation in which the verb derived by means of the original jan suffix has a causative-factitive meaning. As shown in the reported examples, no traces of the phonetic context motivating Umlaut are present in these verbs. Rather, the weakening of the final unstressed vowels has levelled out the deverbal jan suffix. As a consequence of reanalysis, the occurrence of Umlaut has been reinterpreted as responsible for the process of derivation. In fact, after Umlaut lost its phonetic motivation by the weakening of unstressed syllables, a number of verbs with factitive-causative meaning that originally did not show -jan suffix take Umlaut in MHG period:

(7) OHG corônôn, MHG krônen/kræenen, NHG krönen 'to crown' OHG offanôn, MHG offenen, NHG öffnen 'to open' OHG rôtên, MHG rôten, NHG röten 'to redden'

My proposal is that beside morphologization of Umlaut as a kind of affix within inflectional morphology, morphologization as a derivational device has also taken place (cf. Robinson 1975). The originally phonological rule illustrated above has been reanalyzed and reinterpreted as a morphological rule of derivation:

$$
(\mathrm{Ur}) \mathrm{c} \quad \mathrm{V} \rightarrow[+ \text { front }] / \quad\left[\begin{array}{l}
+ \text { Verb } \\
+ \text { Causative }
\end{array}\right]
$$

This morphological rule of derivation still survives, at least partially, in NHG, where the following doublets (cf. Wellmann 1973: 24) are to be found:

(8) lahmen 'to be lame' : lähmen 'to paralyze' blauen 'to be blue' : bläuen 'to dye blue' dampfen 'to steam' : dämpfen 'to steam (cook.)' tafeln 'to have dinner' : täfeln 'to cover with panels'

\subsection{Grammaticalization vs. analogy: The case of Rückumlaut}

The effects of a reanalysis in which the rule is associated with certain grammatical features are crucial in distinguishing this phenomenon of grammaticalization from the contemporary (and apparently similar) case of Rückumlaut (cf. Vennemann 1986, Ronneberger-Sibold 1990). The latter is an instance of rule inversion, in which a generalization of the inverse rule has taken place on the basis of the occurrence of the sound alternation in a secondary semantic category (cf. Vennemann 1974: 139). In the OHG period, as a consequence of the loss of phonetic motivation for the Umlaut rule, the following verbal paradigms emerged:

(9) brennen brannte gebrannt 'to burn'
senden sandte gesandt 'to send'

This alternation concerned verbs of the -jan class (*brannjan, *sandjan), which displayed, at least historically, particular phonological properties. Here, a rule of Syncope deleted the $-j$ - in a light syllable between a primary-stressed heavy syllable and a secondary-stressed one, but the same has not happened to the glide of the infinitive (cf. *brannjan vs. *brannda, see Vennemann 1986 for details). The rule of Umlaut must be ordered after the Syncope rule in order to provide the correct form. Interestingly, Rückumlaut has been extended analogically in the MHG period to some other verbs:

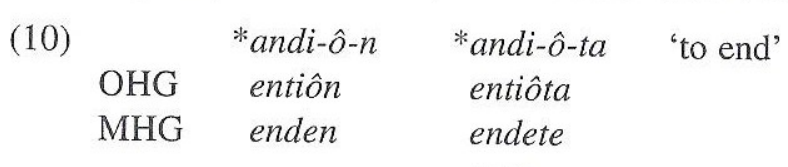


In the form ante, the same alternation occurs as in senden - sandte. Vennemann speaks in this instance of rule inversion. Where originally the phonological rule of Umlaut caused sound alternations within the verbal paradigm, a restructuring that has inverted the interpretation of the surface forms has taken place. The real change is assumed to occur in the preterital form - a secondary semantic category with respect to the present tense that now alternates with the present on the basis of the well attested model senden - sandte.

However, the comparison of the latter case with the instances of grammaticalization that we presented above (even though determined by the same Umlaut rule) will show the significant difference existing between them. In the former case, we observed an example of grammaticalization, in which the extension of the umlauted forms was closely connected with the birth of a new derivational rule within the grammar of MHG. In the latter, it is a surface analogy that triggers the reinterpretation of the sound alternation, not giving rise to a new rule within the grammar. In fact, no new combinations of grammatical features take place to characterize grammatically this particular (and in MHG opaque) inflectional paradigm. It is my opinion that grammaticalization can be quite useful to distinguish accurately between the two types of phenomena. Note that Vennemann also, in his early paper on rule inversion, concludes that "the domain of rule inversion within this class [i.e. among allophonic, phonemic, morphophonemic and morphological rules, LG] is the phonemic and morphophonemic rules." (1972: 236). In this way, he restricts the domain of rule inversion to those cases where no grammaticalization is observable, since the phonetic motivation of the rule is not replaced by a semiotic motivation (cf. Wurzel's quotation above). Only in those cases where no reanalysis with consequent grammaticalization takes place can we really speak of analogy in its original sense of a restructuring of grammar aimed at "repairing" it, as in Paul's first formulation. ${ }^{6}$ In Hopper \& Traugott's (1993: 56) words, "analogy refers to the attraction of extant forms to already existing constructions ... It is overt", whereas "reanalysis refers to the development of new out of old structures ... It is covert." It must be specified, however, that reanalysis has to give rise to new grammaticalized structures, i.e. new combination of features. In the case of Rückumlaut such a new combination does not take place, and it is in fact impossible to state a morphological rule that could show which verbs must undergo it, in so far as they are provided with particular properties and fulfill a specific grammatical target. Rather, it can be suggested which verbs can undergo Rückumlaut on account of their closeness (primarily in their phonetic substance) to the analogical model. Therefore it is in this sense that Vennemann (1986) gives wide documentation of these analogical extensions, without providing, however, a full formulation of this supposed grammatical rule.

\subsection{Syntactic grammaticalization}

Up to now we have been examinating cases of grammaticalization of phonological rules restricted to the word. One can speculate further about other instances of morphologization of earlier phonological rules that have wider field of application than the word. It is interesting to look for other cases of reanalysis in which originally phonological rules become grammaticalized in syntactic fields like the noun phrase or the sentence. In this perspective, a good example of affix creation can be taken from Bulgarian. In Old Church Slavonic there was a dissimilation rule that changed the phonetic value of the so-called jers (cf. Jetchev 1994 and Lunt 1974) in the context of the phonological word:

$$
\text { (11) }\left[\begin{array}{l}
\mathrm{I} / \\
\mathrm{J} / \mathrm{J}
\end{array}\right] \rightarrow\left[\begin{array}{l}
\mathrm{e} / \\
\mathrm{o} /
\end{array}\right] / \mathrm{C} \mathrm{C}_{1} / \mathrm{I}, \mathrm{J} / \mathrm{\phi}
$$

where $\phi$ stands for phonological word

Thereafter, in Bulgarian a deletion rule cancelled those jers that did not undergo the dissimilation rule in (11). However, whereas in other lexical morphemes both outcomes are kept distinct, giving rise to two different phonemes (as shown in (12)),

$$
\text { (12) a. } / U />/ 8 / \text {, cf. ['lakrt] <*[lakutI] "elbow' }
$$$$
\text { b. } / \mathrm{l} />/ \mathrm{e} /, \quad \text { cf. }[\text { den }]<*[\operatorname{din} u]<\text { 'day' }
$$

in the case of the masculine definite article a conflation takes place:

(13) a. * $\left[\mathrm{t} \int\right.$ oveku-tu $]>*[\mathrm{t}$ oveko-tu $]>\left[\mathrm{t} \int \mathrm{o}^{\prime} \mathrm{vekr}\right] \quad$ 'the man' b. *[ogunI-tu] $>*$ [ogone-tu] $>$ ['ogrny, 'ogrny] 'the fire'

In $(13 b)-/ \gamma /$ is identified as the new form of the masculine definite article $(<$ $* / t u /)$, in paradigmatic relation to [3e'na-ta] 'the woman' and [po'le-to] 'the 
field (nt.)', and therefore extended also to those cases like the reported ['ogrny], where we would expect phonetically *['ogrne]. ${ }^{7}$ Thence, we can assume in diachrony that (11) was redetermined by inserting morphological features in its context so as to give rise to a new semiotic motivation of the original phonological alternation:

$$
* / \mathrm{s} / \mathrm{s} / / \quad\left[\begin{array}{l}
+ \text { det. } \\
+ \text { def. } \\
+ \text { masc. }
\end{array}\right]
$$

Once redetermination took place, the new affix was extended to the cases in (13b). (14) dropped subsequently out since it did not give rise to synchronic morphological alternations.

A similar point can also be made in relation to the Umlaut rule illustrated above. Some scholars (cf. Behaghel 19285: 292) have assumed that the umlauted forms found in the plural present indicative of the so called "Präterito-Präsentien" in $\mathrm{OHG}$ (and still in NHG) are due to the co-occurrence with the clitic pronominal forms containing a palatal vowel triggering Umlaut. In some cases, in fact, Umlaut is triggered in OHG, and still in the MHG period, by clitic particles across the word boundaries (cf. Behaghel 1928: 292):

$$
\begin{aligned}
& \text { (15) sem mir < sam mir 'with me' } \\
& \text { drenk-ich }<\text { drank-ich 'I drank' }
\end{aligned}
$$

These phenomena show that Umlaut had, in particular conditions, a larger context than one used to assume, namely the phonological word (cf. Priebsch \& Collinson 19625: 137). However, the question has been scarcely debated in the literature and even recent reviews of the entire question barely mention it (cf. Voyles 1991). In Behaghel's opinion, it has been the co-occurrence of the clitic pronominal particles that has caused the presence of Umlaut in the plural present indicative of the "Präterito-Präsentien": MHG wir dürfen, günnen,

\begin{tabular}{|c|c|c|c|}
\hline \multirow{2}{*}{\multicolumn{2}{|c|}{ (16) Alen }} & chömme $(<$ cho + mer $)$ & 'we come' \\
\hline & & stömmer & 'we stay' \\
\hline & Bav & $\begin{array}{l}\text { gengemer } \\
\text { stendemer }\end{array}$ & $\begin{array}{l}\text { 'we go' } \\
\text { 'we stay' }\end{array}$ \\
\hline
\end{tabular}
künnen, mügen (megen), müezen, sülen. These forms can be paralleled with the following forms taken from High German dialects:
According to Behaghel's subsequent explanation, the umlauted forms, originally the result of phonological Umlaut, have been morphologized only in the plural present indicative (whence they passed to the infinitive) of this verbal class. This explanation has met with several objections (cf. Fiedler 1928, Sčur 1961/62). First, there are only a few cases where syntactic Umlaut is reported in the manuscripts. This is of course true, but it does not necessarily speak against Behaghel's theory. It is clear that an allophonic variation like Umlaut is reflected only sporadically in writing (at least until it becomes phonologized or grammaticalized). Probably, those cases where umlauted forms occurred in contexts wider than those of a single word were even more sporadically reflected. Only at a later stage, when these umlauted forms had slowly been grammaticalized as signals of this specific conjugational class, do we find a regular notation of the umlauted vowels. On the contrary, since Umlaut lost phonetic motivation in the course of the OHG period, those cases where umlauted vowels emerged such as the examples in (15) disappeared completely.

Second, this explanation avoids the difficulties shown by the other theory, the Rückumlaut theory (cf. Fiedler 1928). According to Fiedler's explanation, the alternation of umlauted forms in the present and non-umlauted forms in the past is due to the action of an analogical extension of the Rückumlaut upon this verbal class.

\section{(17) legen $\rightarrow$ lahte $: \underline{\text { megen }} \leftarrow$ mahte}

However, the theory is in my opinion unconvincing because the analogical reinterpretation must take place here inversely with respect to its normal behaviour. As we have seen above, the (semantically) secondary forms of the past are usually remade on the basis of the inverted rule. If we agree with Fiedler's explanation, we must assume that the analogical conditioning has operated in the opposite way as it normally did ad hoc for this verbal class. In any case, I am convinced that the whole question needs a complete revision and a separate contribution. My intention has merely been to suggest how different examples of morphologization can be found within the same original phonological rule. To quote just another case of a grammaticalized phonological rule that may be compared with what has been said in this paragraph, it may be useful to consider the case of some dialects of central-northern Calabria (cf. Loporcaro 1995), where specific verbal forms (i.e. the $3^{\text {rd }}$ plural person of the present) trigger the lengthening of the initial consonant of the 
following word in external sandhi (well known as "Raddoppiamento Fonosintattico"):
(18) [t $\mathrm{te}$ 'ßiru 'p:sku]
['țiku 's:empre]
'they can't see well'
'they always come late'

This lengthening represents the survival, on the segmental level, of an earlier assimilation rule which in its turn assimilated an original Latin dental ending consonant to the following one. In this case, the whole suffix - $(u) n t$ is assimilated:

$$
\text { (19) ['ßiru 'p:oku] < *vidunt pocu }
$$

That this assimilation rule is now only morphologically governed is shown by the following example, where the lengthening is the only feature that keeps the two inflectional forms distinct:

$$
\begin{aligned}
& \text { (20) ['ruormu 'p:uru] vs. ['ruormu 'puru] } \\
& \text { 'they also sleep' }
\end{aligned}
$$

Notice that the phonological rule is fully grammaticalized inasmuch as no relevant features are superficially available to trigger the rule of lengthening; only reference to the morphosyntactic information can lead to the correct application of the rule:

(21)

$$
\mathrm{C} \rightarrow \mathrm{C}: / \quad\left[\begin{array}{l}
+ \text { Verb } \\
+ \text { Present } \\
\text { III Person } \\
+ \text { Plural }
\end{array}\right]-
$$

In this sense, semiotic remotivation (in Wurzel's terms) of the originally phonetic rule has taken place. Sometimes, among the world languages, we find cases of grammaticalization of phonological rules that give rise to alternations expressing syntactic relations. ${ }^{8}$ In this perspective, a very interesting example comes from the Celtic languages, that show a wide range of phenomena of external sandhi rules well known as Initial Consonant Mutations (cf. Awbery 1986, Willis 1986). In Welsh, for instance, there are several cases of mutations concerning word-initial consonants. A case particularly relevant for my purposes is the lenition of initial consonants when preceded by a specific set of words. Diachronically the lenition is triggered by a preceding vowel, later disappeared (cf. Lewis \& Pedersen 1937: 127). Simi- larly to other instances of mutations such as spirantization, nasalization, etc., lenition takes place in several contexts either triggered by an immediately preceding word (so-called "projected mutations") or without an apparent trigger ("incorporated mutations", cf. Willis 1986: 16). The latter cases are probably to be interpreted as cases of grammaticalization in the syntactic domain, since the mutation occurs in words that surface as direct objects, independently both of the preceding word and of the position of the verb: ${ }^{9}$

$$
\begin{aligned}
& \text { (22) a. } \text { clywodd Sion gi }(<c i) \\
& \text { heard Sion dog } \\
& \text { 'Sion heard a dog' } \\
& \text { b. } c l y w o d d \text { gi }(<c i) \\
& \text { 'S/he heard a dog' } \\
& \text { c. } c l y w o d d ~ c i \\
& \text { 'A dog heard' }
\end{aligned}
$$

Notice that lenition is crucial in distinguishing (22b) from (22c) in which $c i$ surfaces as the subject. ${ }^{10}$ Lenition, however, can be found in other contexts, occurring both word-internally and within syntactic phrases. These cases can often be explained as instances of grammaticalizations. For example, feminine nouns are lenited after the singular feminine article, so as to distinguish the following pair:

(23) $y \operatorname{gog}(<\operatorname{cog})$ vs. $y \operatorname{cog}$

$$
\text { the (fem.) cuckoo the (masc.) cook }
$$

As can be seen from this rather sketchy representation, the question of the Celtic mutations is extremely intricate. In my opinion, the notion of grammaticalization can shed some light on the matter, avoiding for example the proliferation of terms for apparently similar changes that we often find in literature. ${ }^{11}$ I think however that the main contribution Celtic mutations bring forth into this discussion concerns the use of the early phonological rule of lenition as a mark of purely syntactic relations (cf. 22b above); in this perspective lenition has been grammaticalized as a kind of case marker. The last example shows how far the process of grammaticalization of phonological rules can move: (the alternation produced by) a phonological rule can be redetermined to express purely syntactic relations. ${ }^{12}$ However, much further research must be done in this field, that is, grammaticalization of phonological rules in the syntactic domain, before we can consider any further generalizations possible. 


\subsection{Concllusion}

The phonological path to grammaticalization has been shown to represent the symmetrical and reverse path with respect to both clines singled out in traditional studies on grammaticalization. Moreover, it turns out that this notion can be useful in distinguishing between morphologizations involving reanalysis of early phonological rules and cases of surface analogy, where the restructuring does not involve grammaticalization in the strict sense. Other "broader" interpretations of analogy, like those recently provided by Becker (1990), are in my opinion to be avoided, although interesting, because of the terminological confusion they lead to. Arguing, as he does, that the formula of analogy and the classical (generative) morphological rule are in principle the same, Becker fails to take into consideration the main difference between a rule and an analogical process (cf. Bauer 1993). This difference is properly that a rule presupposes the presence of a process of grammaticalization that could "license" it, whereas analogy, in its strict sense, only concerns surface relations among already grammatical entities.

\section{NOTES}

1. Cf. Joseph \& Janda (1988: 196): "The diachronic phenomenon of morphologization is exemplified by the movement of syntactic phenomena into morphology as well as by the movement of phonological phenomena into that domain".

2. Cf. Salmons (1994) for criticisms that however do not concern the global interpretation of German Umlaut as a case of morphologization of a phonological alternation. Unfortunately, generative phonology does not seem to share the same interpretation of umlauting, since it still provides a phonology-driven description of the above alternations, even though moderated by a two-level lexicalist framework (cf. Wiese 1996).

3. For a discussion of the relationship between grammaticalization and lexicalization, cf Lehmann (1989).

4. Cf. Hopper \& Traugott (1993: 148), Matisoff (1991). Hopper \& Traugott (1993: 149) observe, moreover, that "there is a tonal change, generally from a lower to a mid or high tone, which is phonetically (albeit indirectly) linked to the voicing change. Where the tone, which is phonetically (albeit indirectly) linked to the voicing change. Where the
initial consonant is one that does not show a distinction in voicing, such as the nasal $[\mathrm{m}]$ or the affricate $[\mathrm{c}]$ in the next example, the tonal difference is the only remaining trace of the former prefix:

(19) a. mò 'see' : mə 'show'

b. câ 'eat' : cā 'feed"'

5. Cf. Paul (1920: 125): "Im Mhd. ist diese Bildungsweise noch einigermaßen lebendig. Im Nhd. sind manche früher vorhandene Bildungen untergegangen".
6. Cf. Kiparksy (1992: 56): "Analogy is sometimes postulated as a supplementary mechanism of derivative generation accounting for the use of utterances that are not directly generatable by the grammar". A completely different question, for which an adequate answer has not yet been found, is why and where, i.e. on the basis of which model, analogy takes place. Cf. the discussion ibidem.

7. Notice that the palatalization triggered in the stems originally containing /I/ and still visible in the form ['ogrny] has practically disappeared in Colloquial Standard Bulgaria (Jetchev's personal communication), removing the last segmental phoneme.

8. In this sense, they become "syntactified", cf. Zwicky (1987: 225): "Syntactification is the counterpart above the level of the word of the familiar phenomenon of morphologization below the level of the word".

9. Cf. Awbery (1986: 417): "The direct object of an inflected verbs undergoes the soft mutation [= lenition, LG] provided that it is phrase-initial in the noun phrase".

10. For a (traditional) explanation of the modern situation, cf. Morris-Jones (1931: 195): "Originally, of course, the case of the noun had nothing to do with its initial mutation; for mutation depends not upon the old ending of the word mutated, but on the general character in Brythonic of the ending of the preceding word. Thus the mutation of the noun depended wholly upon the form of the verb. The development of the modern rule is in outline as follows: The 3 rd pers. sing. was differentiated from the other persons by the fact that it could be followed by subjects and objects, while the others could be followed by objects only. Now, it appears that the 3rd pers. sing. generally ended in a consonant in Brythonic as in Latin, except in the imperfect tense; hence in Medieval Welsh both subject and object after the 3rd sing. have the radical [unlenited consonant, LG] with a large proportion of the soft [lenited consonant, LG] after imperfect. The other persons mostly ended in vowels, thus caraf ('I sing') represents *arami; hence the soft came to
margersons be associated with the object. Thus a new basis of mutation was unconsciously evolved; exceptions were gradually done away with, and the radical became the sign of the subject, the soft of the object." For another interpretation of the Welsh mutation, cf. King (1993: 22-3), criticized however by Alan R. King on the Linguist List 7.1046.

11. Cf. Awbery (1975), who speaks of lexical, categorial, structural and transformational mutation.

12. However, my opinion is that there are still many possible cases to be found: for example, an early phonological rule that has assumed a grammatical content, which makes reference to the domain of the sentence, e.g. becoming an interrogative marker.

\section{REFERENCES}

Awbery, Gwenllian M. 1975. "Welsh mutations: Syntax or phonology?" Archivum Linguisticum 6: 14-25.

. 1986. "Survey of sandhi types in Welsh." In Henning Andersen (ed.), Sandhi Phenomena in the Languages of Europe, 415-33. Berlin-New York-Amsterdam: Mouton de Gruyter [Trends in Linguistics. Studies and Monographs 33]. 
Bauer, Laurie. 1993. Review Article of Becker (1990). In Geert Booij and Jaap van Marle (eds),Yearbook of Morphology 1992, Dordrecht: Kluwer, 264-7.

Becker, Thomas. 1990. Analogie und morphologische Theorie. Munich: Fink.

Behaghel, Otto. 19285. Geschichte der deutschen Sprache. $5^{\text {th }}$ ed. Berlin and Leipzig: de Gruyter [Grundriss der germanischen Philologie 3].

Bybee, Joan L. 1985. Morphology. A Study of the Relation between Meaning and Form. Amsterdam/Philadelphia: John Benjamins [Typological Studies in Language 9].

Dressler, Wolfgang U. 1985. Morphonology. The Dynamics of Derivation. Ann Arbor: Karoma Press.

Fiedler, H.G. 1928. "Two Problems of the German Preterite-Present Verbs." The Modern Language Review 23: 188-96.

Greenberg, Joseph H. 1991. "The last stages of grammatical elements: Contractive and expansive desemanticization." In Traugott \& Heine (eds), vol. 1, 301-14.

Hopper, Paul J. 1994. "Phonogenesis." In William Pagliuca (ed.), Perspectives on Grammaticalization, 29-45. Amsterdam/Philadelphia: John Benjamins [Current Issues in Linguistic Theory 109].

Hopper, Paul J. and Elizabeth C. Traugott. 1993. Grammaticalization. Cambridge: Cambridge University Press [Cambridge Textbooks in Linguistics].

Jetchev, Georgi. 1994. "From early Slavic to modern Bulgarian: a survey of changes in the vowel system and the syllable structure." Quaderni del Laboratorio di Linguistica della Scuola Normale Superiore di Pisa 8: 108-14.

Joseph, Brian D. and Richard D. Janda. 1988. "The how and why of diachronic morphologization and demorphologization." In Michael Hammond \& Michael Noonan (eds), Theoretical Morphology, 193-210. San Diego: Academic Press.

King, Gareth. 1993. Modern Welsh: A Comprehensive Grammar. London: Routledge [Routledge Grammars].

Kiparsky, Paul. 1992. "Analogy.” In William Bright (ed.), International Encyclopedia of Linguistics, vol. 1, 56-61. New York-Oxford: Oxford University Press.

Klausenburger, Jürgen. 1979. Morphologization: Studies in Latin and Romance Morphophonology. Tübingen: Niemeyer [Linguistische Arbeiten 71].

Krämer, Peter. 1971. Die Präsensklassen des germanischen schwachen Verbums. Innsbruck: Innsbrucker Beiträge zur Sprachwissenschaft.

Lehmann, Christian. 1989. "Grammatikalisierung und Lexikalisierung." Zeitschrift für Phonetik, Sprachwissenschaft und Kommunikationsforschung 42/1: 11-9.

Lewis, Henry and Holger Pedersen. 1937. A Concise Comparative Celtic Grammar. Göttingen: Vandenhoeck \& Ruprecht.

Loporcaro, Michele. 1995. "Raddoppiamento fonosintattico dopo III persone plurali del verbo nei dialetti di Conflenti (CZ) e di San Giovanni in Fiore (CS)." Rendiconti della Classe di Scienze Morali, Storiche e Filologiche dell'Accademia Nazionale dei Lincei, s. 9 , v. $6,543-53$.

Lunt, Horace G. 1974. Old Church Slavonic. The Hague: Mouton.

Matisoff, James A. 1991. "Areal and universal dimensions of grammaticization in Lahu." In Traugott \& Heine (eds), vol. 2, 383-453.

Meillet, Antoine. 1912. "L'évolution des formes grammaticales." Reprinted in Antoine Meillet. 1948. Linguistique historique et linguistique générale, Paris: Champion, 13048 .
Meillet, Antoine. $1930^{4}$. Caractères généraux des langues germaniques. $4^{\text {th }}$ ed. Paris: Hachette.

Morris-Jones, John 1931. Welsh Syntax. An Unified Draft. Cardiff: The University of Wales Press Board.

Paul, Hermann. 1920. Deutsche Grammatik. V Bd. Teil IV: Wortbildungslehre. Halle/S.: Niemeyer.

Priebsch, R. and W.E. Collinson. $1962^{5}$. The German Language. $5^{\text {th }}$ ed. London: Faber \& Faber.

Robinson, Orrin W. 1975. "Abstract phonology and the history of umlaut." Lingua 37: 129.

Ronneberger-Sibold, Elke. 1990. "Zum Auf- und Abbau des Rückumlauts bei den schwachen Verben." In Armin Bassarak et al. (eds), Wurzel(n) der Natürlichkeit. Studien zur Morphologie und Phonologie IV. Berlin: Akademie der Wissenschaften der DDR [Linguistische Studien. Reihe A. 208].

Salmons, Joseph C. 1994. "Umlaut and plurality in Old High German. Some Problems with a natural morphology account.” Diachronica 11: 213-29.

Sčur, Georgij S. 1961. "Über den Umlaut der deutschen Modalverben." Neuphilologische Mitteilungen 62: 206-19.

Traugott, Elisabeth C. and Bernhard Heine (eds). 1991. Approaches to Grammaticalization, Amsterdam/Philadelphia: John Benjamins [Typological Studies in Language 19], 2 vols.

Vennemann, Theo. 1972. "Rule inversion." Lingua 29: 209-42.

1974. "Restructuring." Lingua 33: 137-56.

1986. "Ruckümlaut." In Dieter Kastovsky and Aleksander Szwedek (eds), Lin guistics across Historical and Geographical Boundaries. In Honour of Jacek Fisiak on the occasion of his 50th birthday, vol. 1, 701-23. Berlin-New York-Amsterdam: Mouton de Gruyter.

Voyles, Joseph. B. 1991. "A History of OHG i-umlaut." Beiträge zur Geschichte der deutschen Sprache und Literatur 113/2: 159-94.

Wellmann, Hans. 1973. Deutsche Wortbildung. Das Verb. Düsseldorf: Schwann.

Wiese, Richard. 1996. "German Umlaut and Ablaut." Journal of Linguistics 32: 113-35.

Willis, Penny 1986. The Initial Consonant Mutations in Welsh and Breton, Bloomington: Indiana University Linguistic Club.

Wilmanns, Wilhelm. $1930^{2}$. Deutsche Grammatik. II Bd.: Wortbildung. $2^{\text {nd }}$ ed. Berlin and Leipzig: de Gruyter.

Wurzel, Wolfgang U. 1980. "Ways of morphologizing phonological rules.” In Jacek Fisiak (ed.), Historical Morphology. The Hague: Mouton [Trends in Linguistics. Studies and Monographs 17], 443-62.

Zwicky, Arnold M. 1987. "French prepositions: no peeking." Phonology Yearbook 4: 21127. 